\title{
Synthesis, Characterization and Evaluation of the Anti-cancer Activity of Silver Nanoparticles by Natural Organic Compounds Extracted from Cyperus sp. rhizomes
}

\author{
Rasim Farraj Muslim¹, Mustafa Nadhim Owaid1,2* \\ 1 Department of Ecology, College of Applied Sciences-Hit, University of Anbar, Hit, Anbar 31007, Iraq. \\ 2Department of Heet Education, General Directorate of Education in Anbar, Ministry of Education, Hit, Anbar 31007, Iraq.
}

\begin{abstract}
The object of this work is biosynthesizing AgNPs from extracts of Cyperus sp. galingale rhizomes, studying their characteristics using UV-visible spectroscopy, AFM, SEM, FTIR, and EDX analyses and testing their anticancer activity (in vitro) against L2OB cell line. Biosynthesizing AgNPs using various plants is considered eco-friendly, cheap, energy saving and reproducible compared with non-green methods. UV-Visible spectrum checked the surface plasmon resonance of AgNPs at $410-420 \mathrm{~nm}$. FT-IR exhibited that the presence of carbonyl and hydroxyl groups in the extract of Cyperus sp. can reduce and stabilize AgNPs. EDX, SEM, and AFM analyses were applied to confirm the nature, morphology and topography of the biosynthesized AgNPs. AgNPs are spherical or irregular in shape with the average diameter of hot extract-AgNPs is $56.31 \mathrm{~nm}$ in comparison with cold extract-AgNPs is $92.53 \mathrm{~nm}$. The hot extract-AgNPs paly a suitable role against mouse cell line (L2OB) which have receptors for polioviruses better than the cold extract-AgNPs.
\end{abstract}

Keywords: SEM, EDS, Green nanotechnology, Galingale, L2oB.

\section{INTRODUCTION}

The synthesis of metallic nanoparticles has become an important issue in recent decades due to their various beneficial and unique properties and biomedical and industrial applications ${ }^{1}$. Nanotechnology is seeking to synthesize nanoparticles have substantial biomedical applications because of their unique characteristics and their green nature due to using some medicinal plants as

*Corresponding Author: Mustafa Nadhim Owaid, email: mustafanowaid@gmail.com

Rasim Farraj Muslim ORCID Number: 0000-0002-8273-2429

Mustafa Nadhim Owaid ORCID Number: 0000-0001-9005-4368

(Received 26 November 2018, accepted 30 December 2018) 
a reducer agent in the biosynthesis of metallic nanoparticles ${ }^{2}$. Silver nanoparticles are considering famous nanoparticles compared with other metallic nanoparticles because of their antibiotic activity against viruses ${ }^{3}$, bacteria ${ }^{4,5}$, fungi ${ }^{6}$, cancers ${ }^{7,8}$, and parasites 9 .

Green synthesis of AgNPs was successfully done in simple, rapid, eco-friendly and a cheaper method using plant leaves extracts like Azadirachta indica ${ }^{10} \mathrm{ra}-$ pid, simple approach was applied for synthesis of silver nanoparticles using Azadirachta indica aqueous leaf extract. The plant extract acts both as reducing agent as well as capping agent. To identify the compounds responsible for reduction of silver ions, the functional groups present in plant extract were investigated by FTIR. Various techniques used to characterize synthesized nanoparticles are DLS, photoluminescence, TEM and UV-Visible spectrophotometer. UV-Visible spectrophotometer showed absorbance peak in range of 436-446 nm. The silver nanoparticles showed antibacterial activities against both gram positive (Staphylococcus aureus, Panax ginseng ${ }^{8}$, Tridax procumbens ${ }^{11}$, Ziziphus nummularia ${ }^{12}$, Thevetia peruviana ${ }^{13}$, olive (Olea europaea) ${ }^{14}$, Cleome viscosa, ${ }^{4}$ and fenugreek (Trigonella foenum-graecum L.) ${ }^{15}$, and applying them in medicine as a green drug against bacteria, fungi and tumors.

Galingale Cyperus rotundus belongs to Cyperaceae (sedge family). C. rotundus L., purple nutsedge as a common name, is a perennial weed with slender, scaly creeping rhizomes, and arising singly from the rhizomes which are about 1-3 cm. its rhizomes are externally blackish in color and white inside with a characteristic odor ${ }^{16,17}$. Watery and ethanol crude extracts of $C$. rotundus rhizomes showed significant effects against gram-negative ${ }^{18}$ and gram-positive bacteria, Candida albicans ${ }^{19,20}$ and fungal pathogens ${ }^{21}$. On the other hand, aqueous extract of $C$. longous has activity against parasitic worms ${ }^{22}$.

Recently, rhizomes of Cyperus rotundus had anticancer effects in a recent Iraqi study ${ }^{7}$, and no studies of Cyperus rhizomes extracts that have been reported in synthesizing silver nanoparticles. Thus we selected these galingale plant rhizomes to biosynthesize AgNPs to arise the value of inhibitory effect of Cyperus sp. toward human cancers in vitro.

However, silver nanoparticles have been biosynthesized from cold and hot extracts of Cyperus sp. galingale rhizomes and studied the nature and characteristics of these nanoparticles using UV-Visible spectroscopy, AFM, SEM, FT-IR and EDX analyses and evaluation of their anticancer activity (in vitro) against L2OB cell line is a receptor for human poliovirus. 


\section{METHODOLOGY}

\section{Rhizomes samples}

Fresh rhizomes of Cyperus sp. galingale were collected from gardens of AlBaghdadi district west of Hit, Iraq on October 2017. The plant has identified in College of Applied Sciences-Hit using identification keys as mentioned in ${ }^{16,17}$.

\section{Aqueous extraction of Cyperus sp. (galingale) rhizomes}

\section{The cold extraction method}

The fresh rhizomes of galingale were cleaned from the soil and residues of roots and washed with tap water and then by distilled water (D.W) as in figure 1. The rhizomes were peeled to remove the black cortex and then extracted. For extraction achievement, $10 \mathrm{~g}$ of the freshly peeled rhizomes of Cyperus sp. was crushed in $100 \mathrm{~mL}$ D.W using a mortar and stored in a freezer for $48 \mathrm{hr}$. The iced extract was slowly dissolved in the room temperature. The whitish aqueous extract was filtered using gauze and then by filter paper Whatman No.1 and centrifuged at $4000 \mathrm{rpm}$ for $10 \mathrm{~min}$. The supernatant was collected by a micropipette and named as cold extract solution (C). The residue was emitted. FT-IR spectrum of the crude extract was achieved to characterize and to compare with AgNPs which are formed later ${ }^{6}$.

\section{The hot extraction method}

The fresh rhizomes were cleaned from the soil and residues of roots and washed with tap water and then by distilled water (D.W) as in figure 1. The rhizomes were peeled to remove the black cortex and then extracted. For extraction achievement, $10 \mathrm{~g}$ of the freshly peeled rhizomes of Cyperus sp. galingale was crushed in $100 \mathrm{~mL}$ D.W using a mortar and boiled in the magnetic stirrer hotplate for $15 \mathrm{~min}$. The whitish aqueous extract was filtered using gauze and centrifuged at $4000 \mathrm{rpm}$ for $15 \mathrm{~min}$ twice. The clear supernatant was collected by a micropipette and named as a hot extract solution $(\mathrm{H})$. The residue was emitted. FT-IR spectra of the crude extract (cold and hot extracts) were done to determine the functional groups comparison with FT-IR spectra of their AgNPs which are formed later ${ }^{6}$.

\section{Biosynthesis of silver nanoparticles}

Only $33.8 \mu$ g of $\mathrm{AgNO}_{3}$ (its purity 99.9\%, AFCO For Metal, China) was dissolved in $200 \mathrm{~mL}$ distilled water (D.W) using the magnetic stirrer hotplate until the completion dissolving was observed to get the final concentration $10^{-3} \mathrm{M}$. Five milliliters of series concentrations of cold and hot galingale extracts (20\%, $40 \%, 60 \%, 80 \%$, and $100 \%$ ) were separately mixed with $5 \mathrm{~mL}$ of $10^{-3} \mathrm{M} \mathrm{AgNO}_{3}$ 
solution in $10-\mathrm{mL}$ test tubes and darkly kept at $25{ }^{\circ} \mathrm{C}$ for three days ${ }^{6}$. From another hand, the second method to biosynthesize AgNPs by heating of $30 \mathrm{~mL}$ each crude galingale extract [cold extract $(\mathrm{C})$ and hot extract $(\mathrm{H})$ ] was separately added drop by drop into two 50omL-flask containing $100 \mathrm{~mL}$ of $10^{-3} \mathrm{M}$ $\mathrm{AgNO}_{3}$ solution using magnetic stirrer hotplate at $60^{\circ} \mathrm{C}$ for $1 \mathrm{hr}$. The change in the mixture color was checked and recorded each $15 \mathrm{~min}$.

\section{Characterization of AgNPs}

Galingale-mediated synthesis of silver nanoparticles (AgNPs) using its cold and hot extracts were characterized using changes in color of the mixture, UVVisible spectroscopy (by spectroscopy: EMC-LAB V-110o Digital, 325-1000 $\mathrm{nm}$, Germany), FT-IR (Fourier Transform Infrared) spectra, SEM (Scanning Electron Microscope), EDX, AFM (Atomic Force Microscope), and SPM (Scanning Probe Microscope) analyses.

\section{Anticancer efficacy}

The anticancer activity of two types of AgNPs against L2oB tumor cell line was evaluated. The colorimetric cell viability MTT assay was used as mentioned by ${ }^{23}$ and 24 . Firstly, $100 \mu \mathrm{L} /$ well of L2OB cells $\left(10^{6}\right.$ cell $\left./ \mathrm{mL}\right)$ were cultured in a 96-wells tissue culture plate. Three concentrations of colloid AgNPs (50\%, 75\% and $100 \%$ ) were applied in this test. Moreover, then $100 \mu \mathrm{L}$ of each concentration was added within each well and incubated at $37^{\circ} \mathrm{C}$ for $48 \mathrm{hr}$. after that, 10 $\mu \mathrm{L}$ of MTT solution ( $5 \mathrm{mg} / \mathrm{mL}$ ) was added to each well and reincubated at 37 ${ }^{\circ} \mathrm{C}$ for $4 \mathrm{hr}$. Finally, $50 \mu \mathrm{L}$ DMSO (dimethyl sulfoxide) was added to each well and incubated for $10 \mathrm{~min}$. L2OB cells were cultured in complete medium without AgNPs or the extract of Cyperus sp. solution as a control. The absorbance was measured for each well at $620 \mathrm{~nm}$ using ELISA reader. The inhibition percentage was calculated according to the equation below:

Growth inhibition percentage $=\frac{(\mathrm{OD} \text { of control wells }- \text { OD of test wells })}{\text { OD of control wells }} \times 100$

\section{Statistical Analysis}

Triplicates of growth inhibition percentage were analyzed by one-way analysis of variance using ANOVA table by SAS program version 9 (SAS Institute Inc., USA). The significance of differences was calculated using Duncan's Multiple Range Test (DMRT). Probability value least than $5 \%$ was considered to be statistically significant. 


\section{RESULTS AND DISCUSSION}

The change in color for the mixture of $\mathrm{AgNO}_{3}$ and the Cyperus rhizomes extract from milky (hot extraction) and bright yellow (cold extraction) to the brown color was exhibited as seen in figure 1. The previous figure also is showing adsorption peaks at $410-420 \mathrm{~nm}$ in comparison with the crude extracts of the peeled rhizomes. Hot extract-AgNPs are showing the widest adsorption (2068 $\left.\mathrm{cm}^{-1}\right)$ than cold extract-AgNPs $\left(1800 \mathrm{~cm}^{-1}\right)$.

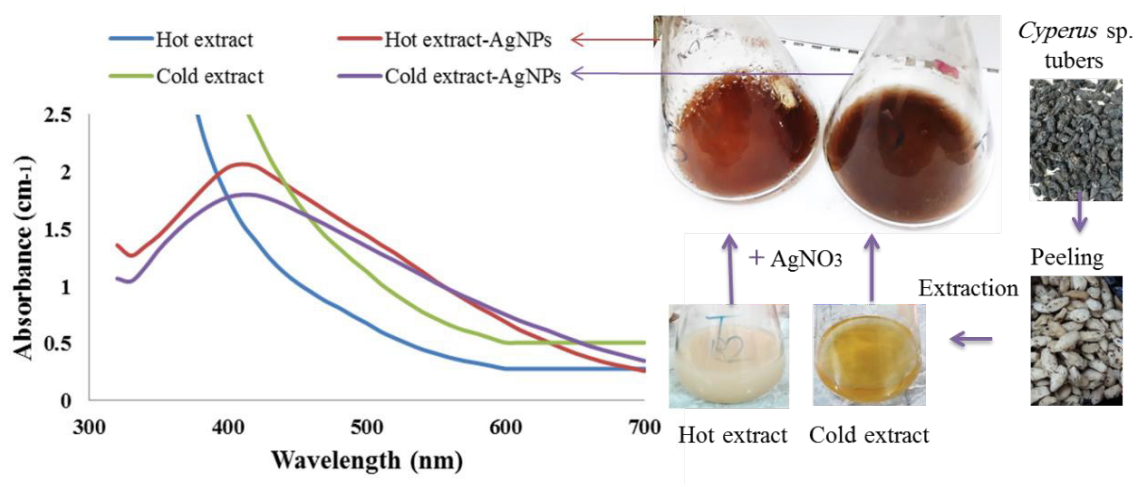

Figure 1. Change in color and UV-Visible spectrum of the biosynthesized AgNPs from Cyperus rhizomes extract

SEM images (figure 2) exhibited the morphology of AgNPs which ranged from spherical to irregular particles. The $3 \mathrm{D}$ and $2 \mathrm{D}$ images of AFM showed the topography of the nanoparticle's surfaces (Figure 3). However, AFM has the advantageousness of probing the surface topography deeply. The AFM image displays the surface morphology of silver nanoparticles synthesized by Cyperus rhizome extracts which reveal the appearance of spherical or irregular and needle-like nanoparticles for the cold extract-AgNPs and the hot extract-AgNPs respectively. Also, roughness average is $7.65 \mathrm{~nm}$ and $7.11 \mathrm{~nm}$; the surface area ratio is $15.3: 1$ and 22.5:1 and the density of summits $258 \mu^{-2}$ and $386 \mu^{-2}$ for the cold extract-AgNPs and the hot extract-AgNPs respectively.

Histogram of particle size distribution (SPM) showed the granularity distribution, volumes and averages of diameters of AgNPs (figure 3). This parameter is affirming the results of AFM images which appears smallness size of the hot extract-AgNPs comparing to the cold ones. The average diameter of the cold extract-AgNPs is $92.53 \mathrm{~nm}$ in comparison with the hot extract-AgNPs is 56.31 $\mathrm{nm}$. Histogram of the particle size distribution of the two AgNPs was presented 
in figure 4 was clear evidence for the formation of silver particles by the percentages of Ag particles in the two treatments.

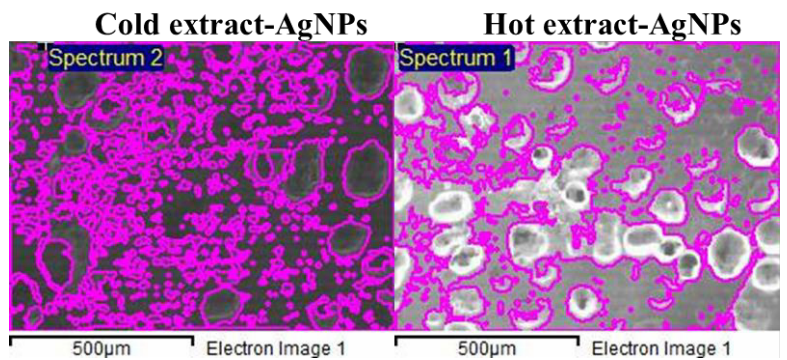

Figure 2. SEM of the biosynthesized silver nanoparticles

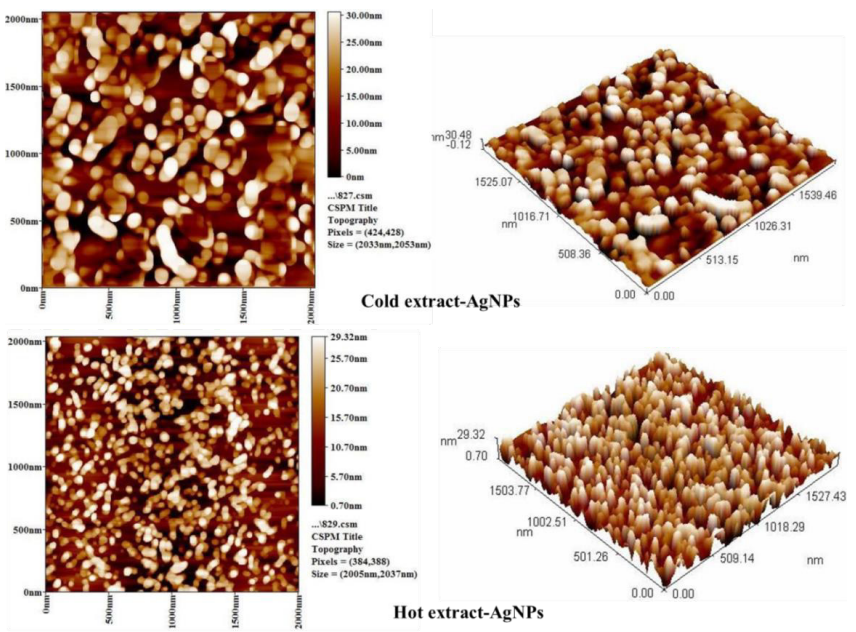

Figure 3. AFM of the colloid silver nanoparticles

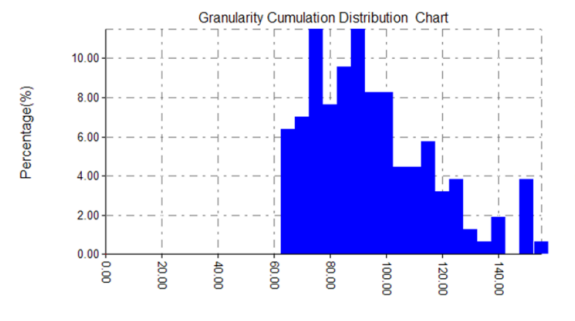

Diameter(nm)

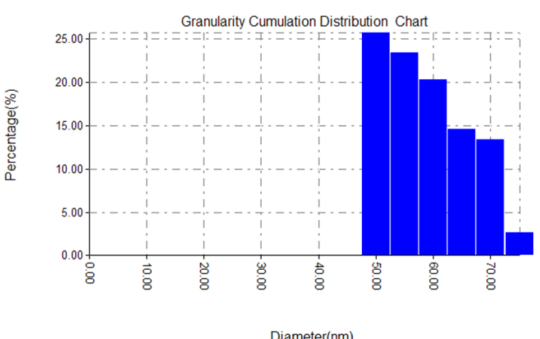

B

Figure 4. Histogram of the particle size distribution of the biosynthesized silver nanoparticles including the cold extract-AgNPs (A) and the hot extract-AgNPs (B) 
The FT-IR spectrum the cold extract (figure $5 \mathrm{~A}$ ) and the hot extract (figure $5 \mathrm{~B}$ ) showed the peak $771 \mathrm{~cm}^{-1}$ is due to the covalent bonding between carbon and silicon (Si-C) and other peaks 1105 cm-1and $1108 \mathrm{~cm}^{-1}$ for cold and hot extracts respectively. These are evidence of linkage of oxygen with silicon in (Si-O). Both spectra also showed two absorption bands at $1384 \mathrm{~cm}^{-1}$ and $1417 \mathrm{~cm}^{-1}$ belong to vibrations of homogeneous and heterogeneous bends of methylene group $\left(-\mathrm{CH}_{2}\right)$ or methyl group $\left(-\mathrm{CH}_{3}\right)$ and two absorption bands at $2891 \mathrm{~cm}^{-1}$ and $2894 \mathrm{~cm}^{-1}$ for cold and hot extracts respectively, and at $2935 \mathrm{~cm}^{-1}$ for cold and hot extracts too. All the mentioned absorption bands belong to the previous groups which presented in the composition of amino acids, peptides or proteins. There were absorption bands at $1053 \mathrm{~cm}^{-1}$ and $1062 \mathrm{~cm}^{-1}$ proved the protein structures for cold and hot extracts respectively belong to the single bond (C-C). The spectra showed absorption bands at $1631 \mathrm{~cm}^{-1}$ and $1633 \mathrm{~cm}^{-1}$ for cold and hot extracts respectively go back to vibrations of stretching of $\mathrm{C}=\mathrm{C}$ group. On another hand, the presence of $\mathrm{C}-\mathrm{H}$-containing compounds $(\mathrm{C}-\mathrm{H})$ is evidenced by the presence of two bands at 3109 and $3130 \mathrm{~cm}^{-1}$ for cold and hot extracts, respectively. It is confirmed that flavonoids, amino acids, peptides, proteins, polyphenols and sugars are present in the presence of a long stretching vibration of the absorption peak at 3396 and $3458 \mathrm{~cm}^{-1}$ for cold and hot extracts respectively. As well as two bending vibration bands at $1384 \mathrm{~cm}^{-1}$ for the cold extract and $1388 \mathrm{~cm}^{-1}$ for the cold extract belong to the hydroxyl groups $(-\mathrm{OH})$; and the absorption band at $1417 \mathrm{~cm}^{-1}$ belongs to the group (C-O).

There are two bands at $1749,1726 \mathrm{~cm}^{-1}$ for cold and hot extracts respectively, although weak. The cause of weakness is probably the multiplicity in these groups and the possibility of a succession that changes this group into a single carbon-oxygen bond. These bands go back to Carbonyl group $(\mathrm{C}=\mathrm{O})$ and this is evidence that the extracts contain flavonoids, mersatin and camphorol. 

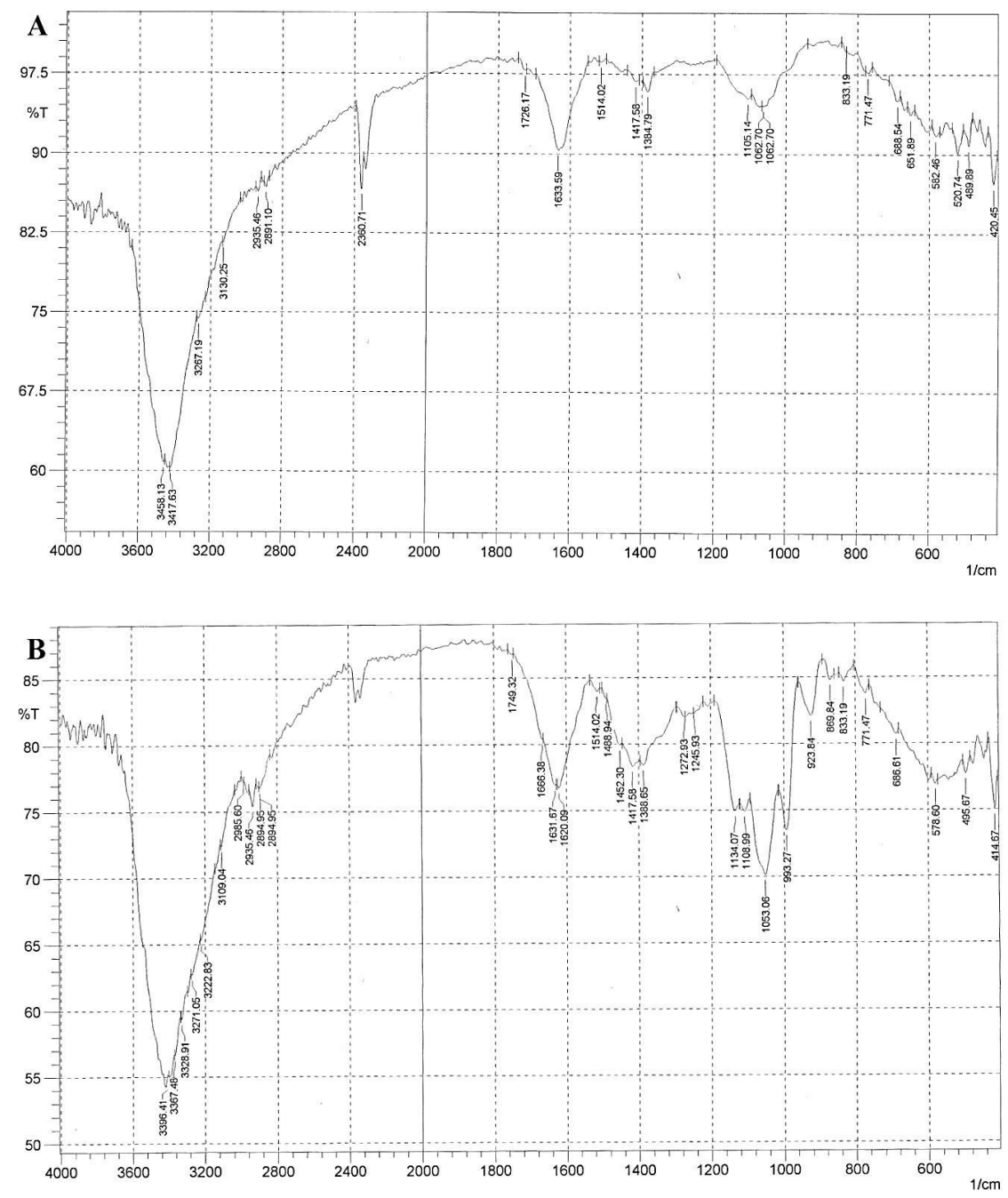

Figure 5. FT-IR of the cold extract $(\mathrm{A})$ and the hot extract $(\mathrm{B})$

As for the FT-IR spectroscopy of silver nanoparticles of the hot and cold extracts, Figures 6A and 6B. The absorption bands at $1132 \mathrm{~cm}^{-1}$ and $1120 \mathrm{~cm}^{-1}$, the two bands at $1382 \mathrm{~cm}^{-1}$ and $1388 \mathrm{~cm}^{-1}$, the two bands at $1421 \mathrm{~cm}^{-1}$ and $1419 \mathrm{~cm}^{-1}$, and the two bands at $1622 \mathrm{~cm}^{-1}$ and $1623 \mathrm{~cm}^{-1}$ for the AgNPs of cold and hot extracts respectively are clear evidence of the presence of silver nanoparticles in the synthesis of the samples. These two spectra are very similar to the infrared spectrum of cold and hot extracts (figure 5) and therefore the composition is not but the insulation, clarity and beam width are better in the infrared spectrum of the nanostructures. 

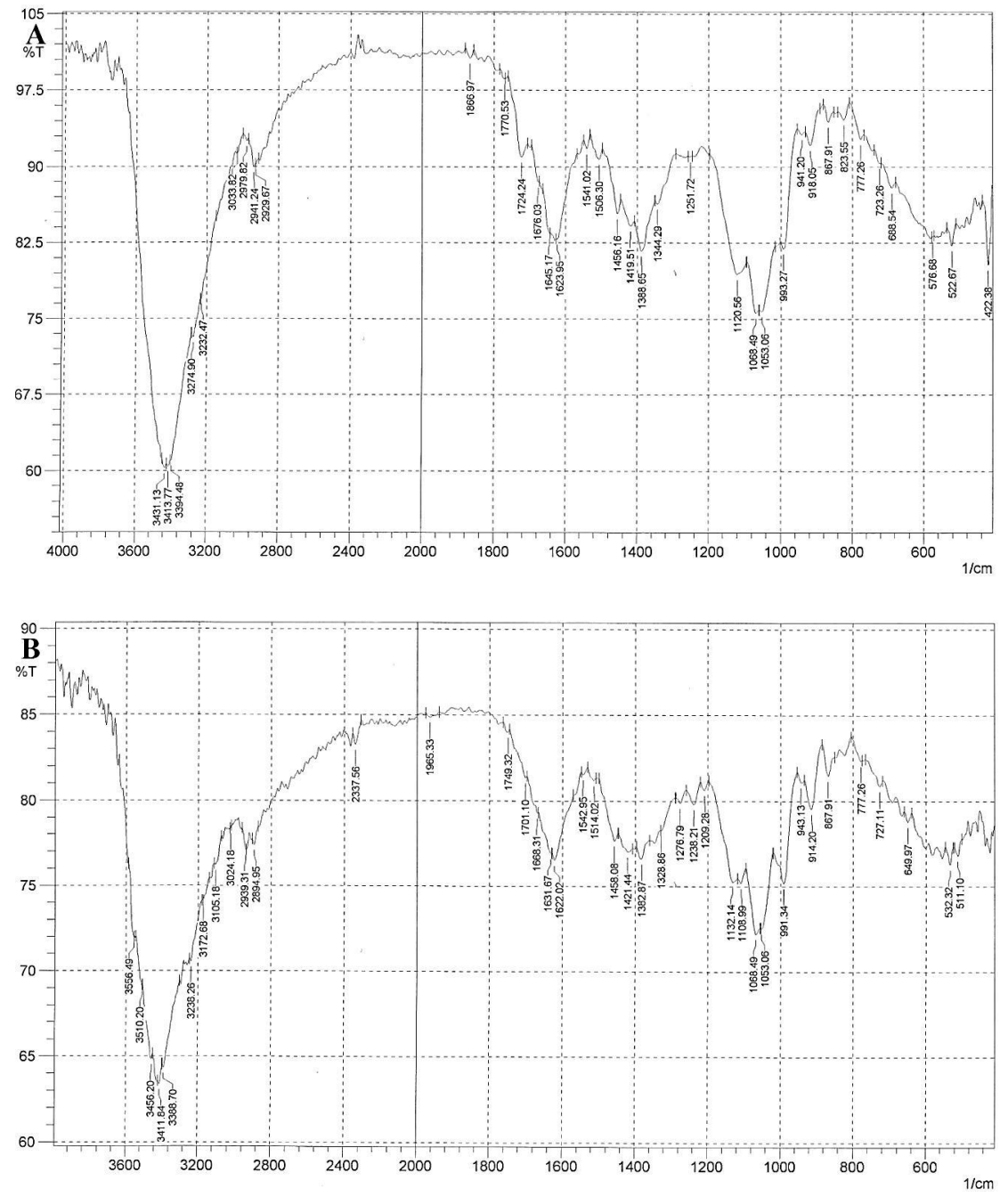

Figure 6. FT-IR of silver nanoparticles of the cold extract (A) and AgNPs of the hot extract (B)

The EDX spectrum of the biosynthesized AgNPs (figure 7) shows finding silver element as an indicator for the formation of silver nanoparticles from the hot extract better than the cold extract. Also, it exhibits the $\mathrm{C}, \mathrm{O}, \mathrm{Cl}, \mathrm{Si}$, and $\mathrm{K}$ elements have been presented in the used sample. 


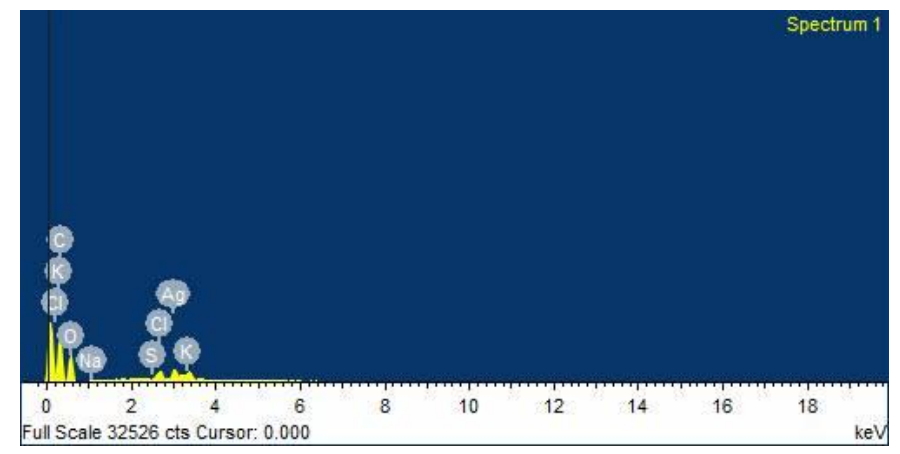

A

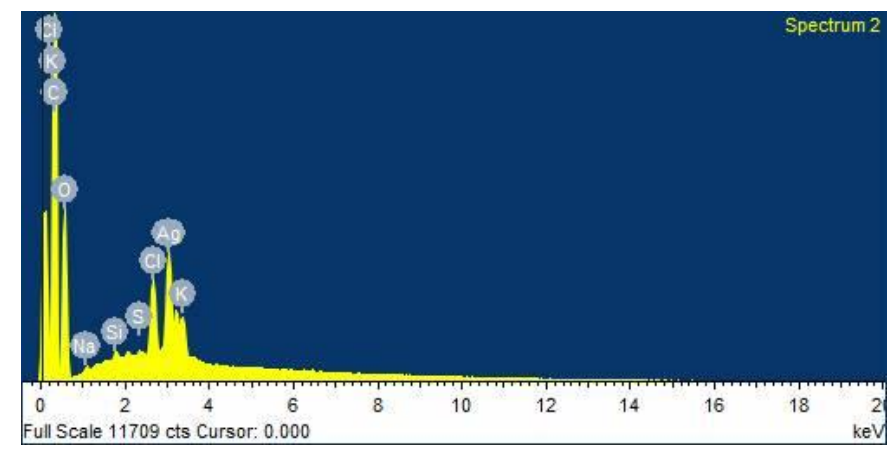

B

Figure 7. EDX images of the colloid AgNPs formed from the hot extract $(A)$ and the cold one (B)

Both the cold extract-AgNPs and the hot-AgNPs were investigated against cell line of murine fibroblast cells have receptors for human polioviruses (L2OB) in vitro. Figure 8 exhibited the anticancer activity of the colloid AgNPs synthesized from aqueous extracts of the peeled Galingale rhizomes. The hot-AgNPs gave better growth inhibition than the cold extract-AgNPs. The best inhibition showed by the concentration $100 \%$ of the hot-AgNPs $35.3 \%$ significantly ( $p<0.01$ ) followed by $22.5 \%$ by the concentration of $75 \%$ of the hot-AgNPs. The concentration $100 \%$ of the cold-AgNPs exhibited $22.4 \%$ then decreased to $17.9 \%$ by the concentration of $75 \%$ of the cold-AgNPs. The concentration $50 \%$ did not show any inhibitory effects as in the crude extracts of Cyperus rhizomes. 


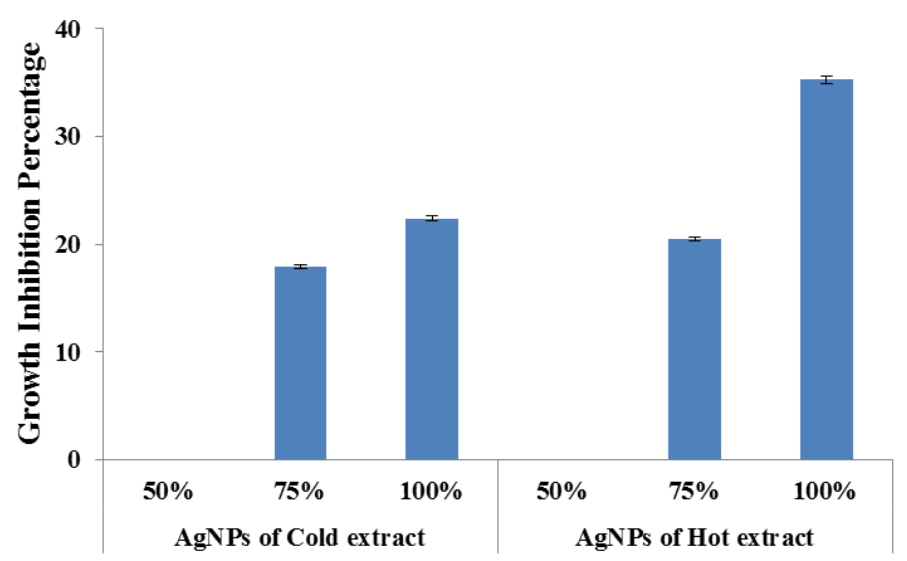

Figure 8. Anticancer activity of the colloid AgNPs synthesized from aqueous extracts of the peeled Galingale rhizomes

The change in color for the mixture of $\mathrm{AgNO}_{3}$ and the Cyperus rhizomes extract from milky (hot extraction) bright yellow (cold extraction) to the brown color is a sign for the formation silver nanoparticles ${ }^{6}$ as seen in figure 1 . The density of brown color is due to excitation of surface plasmon vibrations in the silver nanoparticles ${ }^{25}$, and that is confirmed using UV-Visible spectra. Hot extractAgNPs are showing the widest adsorption $\left(2068 \mathrm{~cm}^{-1}\right)$ than cold extract-AgNPs $\left(1800 \mathrm{~cm}^{-1}\right)$, because of the resonance wavelength of silver nanoparticles has strong depending on Ag atoms, size and morphology of particles ${ }^{26}$.

SEM, AFM and Histogram of particle size distribution (SPM) were used to confirm the nature, topography, morphology of the silver nanoparticles. SEM images (figure 2) exhibited the morphology of AgNPs which ranged from spherical to irregular particles. The shape of silver nanoparticles agreed with many recent studies ${ }^{27}$. The $3 \mathrm{D}$ and $2 \mathrm{D}$ images of $\mathrm{AFM}$ showed the topography of the nanoparticles surfaces (figure 3). Atomic Force Microscope is a useful tool to study different morphological parameters. AFM images as in figure 3 show high-resolution topography and the silver nanoparticles can be visualized under the dry condition ${ }^{28}$.

However, AFM has the advantageousness of probing the surface topography deeply due to its lateral and trial dimensions in nanometer scale resolution 29. The AFM image displays the surface morphology of silver nanoparticles synthesized by Cyperus rhizome extracts which reveal the appearance of spherical or irregular and needle-like nanoparticles for the cold extract-AgNPs and 
the hot extract-AgNPs respectively. Also, roughness average, the surface area ratio and the density of summits are evidence to form the smallest nanoparticles for AgNPs formed from the hot extract of Cyperus rhizome and more summits by high surface area ratio.

Histogram of particle size distribution (SPM) showed the granularity distribution, volumes and averages of diameters of AgNPs (figure 3). This parameter is affirming the results of AFM images which appears smallness size of the hot extract-AgNPs comparing to the cold ones. The average diameter of the cold extract-AgNPs is $92.53 \mathrm{~nm}$ in comparison with the hot extract-AgNPs is $56.31 \mathrm{~nm}$. The reason for this phenomenon is related to the extraction technique which means the heating process during preparation of the herbal extracts leads to destroying active ingredients ${ }^{30}$. Then the interaction of the finer biomolecules with silver ions leads to synthesize finer nanoparticles. Histogram of the particle size distribution of the two AgNPs was presented in Figure 4 was clear evidence for the formation of silver particles by the percentages of Ag particles in the two treatments. All sizes of the biosynthesized AgNPs in the colloids are lesser than $100 \mathrm{~nm}$ which is considered a definite proof for the formation of AgNPs ${ }^{31}$.

Fourier Transform Infrared spectrum (FT-IR) was used to determine the chemical structure and the functional groups. In cold and hot extracts, the similarities were observed in the peak sites. The FT-IR spectrum the cold extract (figure $5 \mathrm{~A}$ ) and the hot extract (figure $5 \mathrm{~B}$ ) confirms the presence of compensated aromatic rings all of which go back to the amino acids, peptides and proteins ${ }^{32}$, amintoflavone and flavonoids ${ }^{33}$ see figure 9 , poly hydroxyl compounds such as myristin, albicaine, camphorol ${ }^{34}$ see figure 10, alkene compounds such as lemons, cocaine and mirentol ${ }^{35}$ see figure 11.<smiles></smiles>

Flavonoids

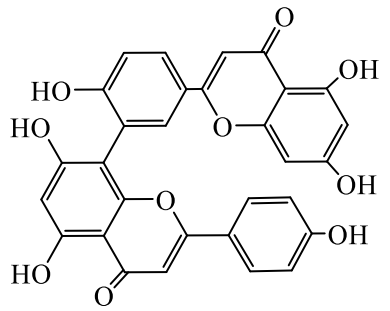

Amentoflavone

Figure 9. Structures of amintoflavone and flavonoids compounds in Cyperus sp. rhizomes 
<smiles>O=c1c(O)c(-c2ccc(O)c(O)c2)oc2cc(O)cc(O)c12</smiles>

Quercetin<smiles>O=c1c(O)c(-c2ccc(O)cc2)oc2cc(O)cc(O)c12</smiles>

Kaempferol<smiles>COc1cc(C2Oc3cc(O)cc(O)c3C(=O)C(O)=C2O)ccc1O</smiles>

Isorhamnetin<smiles>O=c1cc(-c2ccc(O)cc2)oc2cc(O)cc(O)c12</smiles>

Apigenin<smiles>COc1cc(-c2cc(=O)c3c(O)cc(O)cc3o2)ccc1O</smiles>

Chrysoeriol<smiles>C[C@@H]1O[C@H](OC[C@H]2O[C@H](Oc3c(-c4ccc(O)c(O)c4)oc4cc(O)cc(O)c4c3=O)[C@H](O)[C@H](O)[C@H]2O)[C@H](O)[C@@H](O)[C@H]1O</smiles>

Myrcetin

Figure 10. Structures of poly hydroxyl compounds in Cyperus sp. rhizomes<smiles>C=C(C)C1CC=C(C)CC1</smiles>

limonene<smiles>CC12CCC(CC1=O)C2(C)C</smiles>

Campholenic aldehyde

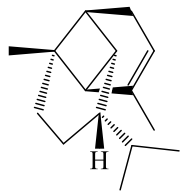

Copaene<smiles>CC1(C)C2CC=C(CO)C1C2</smiles>

Myrtenol

Figure 11. Structures of alkene compounds in Cyperus sp. rhizomes

The absorption bands at $2891 \mathrm{~cm}^{-1}$ and $2894 \mathrm{~cm}^{-1}$ for cold and hot extracts respectively, and at $2935 \mathrm{~cm}^{-1}$ for cold and hot extracts also belong to vibrations of homogeneous and heterogeneous stretching of a methylene group $\left(-\mathrm{CH}_{2}\right)$ or a methyl group $\left(-\mathrm{CH}_{3}\right){ }^{36}$. This research includes synthesis of new heterocyclic derivatives of disubstituted 1,3-oxazepine-5-one. Azomethine compounds (N1-N5 . The spectra showed absorption bands at $1631 \mathrm{~cm}^{-1}$ and $1633 \mathrm{~cm}^{-1}$ for cold and hot extracts respectively go back to vibrations of stretching of $\mathrm{C}=\mathrm{C}$ group belongs to the alkene compounds and the successive double bonds in the benzene ring in the aromatic structures ${ }^{37}$. As well as two bending vibration bands at $1384 \mathrm{~cm}^{-1}$ for the cold extract and $1388 \mathrm{~cm}^{-1}$ for the cold extract belong to the hydroxyl groups $(-\mathrm{OH})$; and the absorption band at $1417 \mathrm{~cm}^{-1}$ due to the stretching vibration of the group (C-O) ${ }^{38}$. The absorption bands $582-578 \mathrm{~cm}^{-1}$ and $688-686 \mathrm{~cm}^{-1}$ for the cold and hot extracts respectively indicate to the amide group $(\mathrm{O}=\mathrm{C}-\mathrm{N}-\mathrm{H})$, which binds two consecutive amino acids in the synthesis of peptides or proteins. The bands at $3267-3271 \mathrm{~cm}^{-1}$ and $3417-3367 \mathrm{~cm}^{-1}$ indicate for the presence of the amine group $\left(-\mathrm{NH}_{2}\right)$ in the synthesis of amino acids, peptides and proteins for cold and hot extracts respectively ${ }^{32,39}$. The presence of the carboxylic group in 
amino acids, peptides and proteins are the appearance of the wide absorption range (2400-3600 $\mathrm{cm}^{-1}$ ) for both extracts and maybe the presence of a carboxylic group (-COOH) in mono acidic saccharides compounds such as glucuronic acid ${ }^{40-43} 3$-oxazepin-5(1H see figure 12.<smiles>O=C[C@H](O)[C@@H](O)[C@H](O)[C@H](O)C(=O)O</smiles>

D- Galacturonic acid<smiles>O=C[C@H](O)[C@H](O)[C@H](O)[C@H](O)C(=O)O</smiles>

D- Glucuronic acid

Figure 12. Structures of mono acidic saccharides compounds in Cyperus sp. rhizomes

The FT-IR spectra of silver nanoparticles of the hot and cold extracts (Figures $6 \mathrm{~A}$ and 6B) showed clear evidence of the presence of silver nanoparticles in the synthesis of the samples because in a study on mushroom found that the silver nanostructure binds with the hydrocarbon's compounds. It shows four packages located nearby and within the ranges listed ${ }^{44}$. These two spectra are very similar to the infrared spectrum of cold and hot extracts and therefore the composition is not, but the insulation, clarity and beam width are better in the infrared spectrum of the nanostructures. The spectrum of silver nanoparticles (Figure 6B) was observed to be similar to Figure $5 \mathrm{~B}$ regarding the sites of the functional groups, but the appearance of the bands was more apparent and better. That may be due to the presence of silver atoms with a high surface area that allows all the atoms with negative electrical and containing pairs of electrons not involved as in the mushroom extract to participate in the silver nanoparticles sample containing the atoms of silver spread well. It is known that the silver atoms contain 47 electrons, so contain in its fifth shell one electron in the second level $5 \mathrm{~s}$. Thus, the other secondary levels are $5 \mathrm{p}$ containing three orbitals, $5 \mathrm{~d}$ containing five orbitals and $4 \mathrm{f}$ containing seven empty orbitals and can accommodate electronic pairs coming from atoms with good negative electrical. The oxygen atom found in the formation of mono crystalline polysaccharides in the form of $(-\mathrm{OH})$ in acid sugars or in the form of $(\mathrm{C}-\mathrm{OO})$ or in the form of carbonyl $(\mathrm{C}=\mathrm{O})$ in male compounds previously, the link is as follows (Ag-OR) where $\mathrm{R}$ is mono crystalline or polyunsaturated sugar or amino acid or Peptide, protein, phenols or flavonoids. Another example of good electrolyte atom is the atom of nitrogen in the form of $(=\mathrm{NH})$ in arginine or the form of $\left(-\mathrm{NH}_{2}\right)$ or $(-\mathrm{NH}-\mathrm{C}=\mathrm{O})$ in peptides and proteins. The association is as follows (Ag-NR) (R) is an amino acid, peptide or protein, 
and the other electrolytic atom is the sulfur atom found in the synthesis of amino acids, peptides and proteins in the form of (-S-) and in the form of (-SH) (Ag-SR) where $\mathrm{R}$ is an amino acid or peptide or protein. FT-IR exhibited that the presence of carbonyl $(\mathrm{C}=\mathrm{O})$ and hydroxyl groups $(-\mathrm{OH})$ in the extract of Cyperus sp. can reduce and stabilize silver nanoparticles ${ }^{13}$.

Carbon and oxygen are presented in the EDX graph (Figure 7) due to the organic molecules which found in the extract of the mushroom. These biomolecules may be amino acids or proteins or polysaccharides or polyphenols which capped the silver nanoparticles as capping and stabilizing agents. The presence of the elemental Ag can be seen in the EDX graph (figure 7) that indicates the reduction of Ag ions to elemental silver ${ }^{45}$. Further, Chlorine is also observed due to the unreacted precursors of $\mathrm{AgNO}_{3}{ }^{46}$.

The silver nanoparticles formed from these rhizomes are exhibiting unique physicochemical and biological activities ${ }^{13}$ thus they have the inhibitory role. The reason of the high inhibitory effects of the hot extract-AgNPs returns to smallness the average of size of these AgNPs ( $56.31 \mathrm{~nm}$ in diameter) in comparison to the average of size of the cold extract-AgNPs (92.53 nm) as in Figure 4 that lead to increase the surface area ratio of the hot extract-AgNPs as AFM in Figure 3.

This study proved the rhizome-mediated synthesis of AgNPs using the cold and hot watery rhizomes extracts of Cyperus sp. FT-IR exhibited that the presence of carbonyl and hydroxyl groups in the extract of Cyperus sp. can reduce and stabilize silver nanoparticles. EDX, SEM, and AFM analyses were confirmed that the biosynthesized silver nanoparticles were spherical or irregular in shape with the average diameter of the hot extract-AgNPs is $56.31 \mathrm{~nm}$ in comparison with the cold extract-AgNPs is $92.53 \mathrm{~nm}$. EDX images indicate to form silver nanoparticles from the hot extract better than the cold one. The synthesized silver nanoparticles were tested against cancer cell line L2OB. The hot extract-AgNPs plays a suitable role against mouse cell line (L2OB) which have receptors for polioviruses better than the cold extract-AgNPs. The best inhibition showed by the concentration $100 \%$ of the hot-AgNPs $35.3 \%$ significantly $(p<0.01)$.

\section{ACKNOWLEDGEMENTS}

The author and co-author are thanking the staff of Department of Ecology, College of Applied Sciences-Hit in University of Anbar to complete project No. 3/122 on 15 Oct 2017. Special thanks to President of the University Prof. Dr. Khalid Battal Najim and Dean of the College, Prof. Dr. Tahseen Ali Zaidan for their continuous support in publishing the research in the certified international journal. Another thank is introducing to the University of Baghdad for achieving the AFM nanophotographic. 


\section{REFERENCES}

1. Rao, C. N. R.; Kulkarni G. U.; Thomas, P. J.; Edwards, P. P. Metal Nanoparticles and Their Assemblies. Chem. Soc. Rev. 2000, 29, 27-35.

2. Karthiga P.; Soranam, R.; Annadurai, G. Alpha-Mangostin, the Major Compound from Garcinia mangostana Linn. Responsible for Synthesis of Ag Nanoparticles: Its Characterization and Evaluation Studies. Nanosci. Nanotechnol. 2012, 2, 46-57.

3. Elechiguerra, J. L.; Burt, J. L.; Morones, J. R.; Camacho-Bragado, A.; Gao, X.; Lara, H. H.; Yacaman, M. J. Interaction of Silver Nanoparticles with HIV-1. J. Nanobiotechnology 2oo5, 3,6 .

4. Lakshmanan, G.; Sathiyaseelan, A.; Kalaichelvan, P. T.; Murugesan, K. Plant-Mediated Synthesis of Silver Nanoparticles Using Fruit Extract of Cleome viscosa L.: Assessment of Their Antibacterial and Anticancer Activity. Karbala Int. J. Mod. Sci. 2018, 4, 61-68.

5. Owaid, M. N.; Muslim, R. F.; Hamad, H. A. Mycosynthesis of Silver Nanoparticles Using Terminia sp. Desert Truffle, Pezizaceae, and Their Antibacterial Activity. Jordan J. Biol. Sci. 2018, 11, 401-405.

6. Owaid, M. N.; Raman, J.; Lakshmanan, H.; Al-Saeedi, S. S. S.; Sabaratnam V.; Ali, I. A. Mycosynthesis of Silver Nanoparticles by Pleurotus cornucopiae var. citrinopileatus and Its Inhibitory Effects against Candida sp. Mater Lett 2015, 153, 186-190.

7. Al-Hilli, Z. A.; Al-Jumaily, E. F.; Yaseen, N. Y. Role of Volatile Oils Fraction of Cyperus rotundus L. in Induction of Apoptosis on Cancer. Iraqi J. Biotech. 2010, 9, 286-298.

8. Castro-Aceituno, V.; Ahn, S.; Simu, S. Y.; Singh, P.; Mathiyalagan, R.; Lee, H. A.; Yang, D.

C. Anticancer Activity of Silver Nanoparticles from Panax ginseng Fresh Leaves in Human Cancer Cells. Biomed Pharmacother. 2016, 84, 158-165.

9. Kalangi, S. K.; Dayakar, A.; Gangappa, D.; Sathyavathi, R.; Maurya, R. S.; Rao, D. N. Biocompatible Silver Nanoparticles Reduced from Anethum graveolens Leaf Extract Augments the Antileishmanial Efficacy of Miltefosine. Exp Parasitol. 2016, 170, 184-192.

10. Ahmed, S.; Saifullah; Ahmad, M.; Swami, B. L.; Ikram, S. Green Synthesis of Silver Nanoparticles Using Azadirachta indica Aqueous Leaf Extract. J. Radiat. Res. Appl. Sci. 2016, 9, 1-7.

11. Sangeetha, R.; Niranjan P.; Dhanalakshmi, N. Characterization of Silver Nanoparticles Synthesized Using the Extract of the Leaves of Tridax procumbens. Res. J. Med. Plant 2016, $10,159-166$.

12. Khan, F. A.; Zahoor, M.; Jalal, A.; Rahman, A. U. Green Synthesis of Silver Nanoparticles by Using Ziziphus nummularia Leaves Aqueous Extract and Their Biological Activities. $J$. Nanomater. 2016, 2016, 8.

13. Oluwaniyi, O. O.; Adegoke, H. I.; Adesuji, E. T.; Alabi, A. B.; Bodede, S. O.; Labulo, A. H.; Oseghale, C. O. Biosynthesis of Silver Nanoparticles Using Aqueous Leaf Extract of Thevetia peruviana Juss and its Antimicrobial Activities. Appl. Nanosci. 2016, 6, 903-912.

14. Nasir, G. A.; Mohammed, A. K.; Samir, H. F. Biosynthesis and Characterization of Silver Nanoparticles Using Olive Leaves Extract and Sorbitol. Iraqi J. Biotechnol. 2016, 15, 22-32.

15. Jasim, B.; Thomas, R.; Mathew J.; Radhakrishnan, E. K. Plant Growth and Diosgenin Enhancement Effect of Silver Nanoparticles in Fenugreek (Trigonella foenum-graecum L.). Saudi Pharm. J. 2017, 25, 443-447. 
16. Kassab, N. H. Antifungal Effect of Some Agents on Candida albicans Growth on Acrylic Resein Denture Base Surface (in vitro Study), University of Mosul, 2002.

17. Chakravarty, H. L. Plant Growth of Iraq (Adictionary of Economic Plants); Botany Directorate, Ministry of Agriculture and Agrarian Reform: Baghdad, 1976.

18. Abdul-Rahman, G. Y.; Rasoul, A. H. Evaluation of the Antibacterial Activity of Cyperus rotundus Extract (an in vitro Study). J. Edu. Sci. 2006, 18, 59-63.

19. Najah, A. M. In Vitro Inhibitory Effect of Cyperus rotundus L. Crude Extracts on Mouth Isolates Streptococcus mutans and Candida albicans. AJPS 2012, 11, 85-91.

20. Ali, M. R.; Hussin, M. S.; Kadum, M. M.; Kadum, Y. A.; Hamza, E. H. In-Vitro Antimicrobial Activities of Myrtus communis L . and Cyperus rotundus L . Extracts. Al-Mustansiriya $J$ Sci 2009, 20, 1-13.

21. Özdemir, Z.; Erincik, Ö. Antimicrobial Activities of Extracts of Cyperus rotundus L . Rhizomes against Some Bacterial and Fungal Pathogens of Strawberry and Tomato. Arch Phytopathol Plant Prot 2015, 48, 850-861.

22. Mustafa, F. A. J. The Aqueous and Alcoholic Extracts of Cyperus longous (Cyperaceae) and Two Drugs (Tinidazole and Praziquantel) on Kiling the Protoscolices of Echinococcus granulosus in vitro. Bas $J$ Vet Res 2009, 8, 148-160.

23. Chih, P. L.; Wei, J. T.; Yuang, L. L.; Yuh, C. K. The Extracts from Nelumbonucifera Suppress Cell Cycle Progression, Cytokine Genes Expression, and Cell Proliferation in Human Peripheral Blood Mononuclear Cells. Life Sci 2oo4, 75, 699-716.

24. Freshney, R. I. Culture of Animal Cell, 6th ed.; Wily-Liss: New York, 2012.

25. Shankar, S. S.; Ahmad, A.; Sastry, M. Geranium Leaf Assisted Biosynthesis of Silver Nanoparticles. Biotechnol. Prog. 2003, 19, 1627-1631.

26. Xia, Y.; Halas, N. Shape-Controlled Synthesis and Surface Plasmonic Properties of Metallic Nanostructures. MRS Bull 2005, 30, 338-344.

27. Owaid, M. N.; Ibraheem, I. J. Mycosynthesis of Nanoparticles Using Edible and Medicinal Mushrooms. Eur J Nanomedicine 2017, 9, 5-23.

28. Rani, P. U.; Rajasekharreddy, P. Plants : The Green Factories for Synthesis of Nanomaterials. In Nanotechnology Vol. 6: Energy and Environment; Govil, J. N., Ed.; Studium Press LLC, USA, 2013; pp 51-78.

29. Farhadi, S.; Ajerloo, B.; Mohammadi, A. Green Biosynthesis of Spherical Silver Nanoparticles by Using Date Palm (Phoenix dactylifera) Fruit Extract and Study of Their Antibacterial and Catalytic Activities. Acta Chim Slov 2017, 64, 129-143.

30. Sasidharan, S.; Chen, Y.; Saravanan, D.; Sundram, K. M.; Yoga Latha, L. Extraction, Isolation and Characterization of Bioactive Compounds from Plants' Extracts. African $J$ Tradit Complement Altern Med 2011, 8, 1-10.

31. Vo-Dinh, T. Protein Nanotechnology, Protocols, Instrumentation, and Applications. In Methods in Molecular Biology; Humana Press Inc.: Totowa, NJ, 2005; pp 1-7.

32. Mistry, B. D. A Handbook of Spectroscopic Data CHEMISTRY (UV, JR, PMR, JJCNMR and Mass Spectroscopy), 2009th ed.; Oxford Book Company, 2009.

33. Ju, Y.; Xiao, B. Chemical Constituents of Cyperus rotundus L . and Their Inhibitory Ef- 
fects on Uterine Fibroids. Afr Health Sci 2016, 16, 1000-1006.

34. Al-Daody, A. C.; Al-Hyaly, A. M.; Al-Soultany, A. A. Chromatographic Identification of Some FlavonoidS Compounds From "Cyperus rotundas" Growing in Iraq. Tikrit J Pure Sci 2010, 15, 218-222.

35. Richa, T.; Suneet, K. Chemical Constituents of the Essential Oil of Cyperus rotundus Linn. Int J Drug Dev Res 2014, 6, 57-60.

36. Muslim, R. F.; Tawfeeq, H. M.; Owaid, M. N.; Abid, O. H. Synthesis, Characterization and Evaluation of Antifungal Activity of Seven-Membered Heterocycles. Acta Pharm Sci 2018, $56,39-57$.

37. Abid, O. H.; Muslim, R. F.; Mohammed, K. M. Synthesis and Characterization of Novel 1,3-Oxazepin-4-Ones Derivatives via Schiff Bases Reactions with Phthalide. J Univ Anbar Pure Sci 2016, 10, 1-9.

38. Abid, O. H.; Muslim, R. F.; Mohammed, K. M. Synthesis and Characterization of Novel 1,3,4,9a-Tetrahydrobenzo[e][1,3]Oxazepin- 5(5aH)-One Derivatives via Cycloaddition Reactions of Schiff Bases. J Univ Al-Anbar Pure Sci 2016, 10, 8-18.

39. Silverstein, R.; Webster, F.; Kiemle, D. Spectrometric Identification of Organic Compounds, 7th ed.; John Wiley and sons, Inc.: London, UK, 2005.

40. Nakamoto, K. Infrared and Raman Spectra of Inorganic and Coordination Compounds Part A: Theory and Applications in Inorganic Chemistry, 6th ed.; A John Wiley and Sons, Inc., 2009.

41. Field, L. D.; Sternhell, S. Kalman, J. R. Organic Structures from Spectra, 4th ed.; John Wiley and Sons Ltd, 2008.

42. Abid, O. H.; Tawfeeq, H. M.; Muslim, R. F. Synthesis and Characterization of Novel 1,3-Oxazepin-5(1H)-One Derivatives via Reaction of Imine Compounds with Isobenzofuran1(3H)-One. Acta Pharm Sci 2017, 55, 43-55.

43. Simek, J. Organic Chemistry, 8th ed.; Pearson education, Inc., 2013.

44. Sujatha, S.; Tamilselvi, S.; Subha, K.; Panneerselvam, A. Studies on Biosynthesis of Silver Nanoparticles Using Mushroom and Its Antibacterial Activities. Int J Curr Microbiol App Sci 2013, 2, 605-614.

45. Al-Bahrani, R.M.; Abdel Majeed, S.M.; Owaid M.N.; Mohammed, A.B.; Rheem, D.A. Phyto-fabrication, characteristics and anti-candidal effects of silver nanoparticles from leaves of Ziziphus mauritiana Lam. Acta Pharm Sci 2018, 56, 85-92.

46. Kathiravan, V.; Ravi, S.; Ashokkumar, S. Synthesis of Silver Nanoparticles from Melia dubia Leaf Extract and Their in vitro Anticancer Activity. Spectrochim Acta Part A Mol Biomol Spectrosc 2014, 130, 116-121. 